\title{
Cytosolic Domain of the Type I Interleukin-1 Receptor Spontaneously Recruits Signaling Molecules to Activate a Proinflammatory Gene
}

\author{
R. Singh, ${ }^{\ddagger}$ S. Huang, T. Guth, ${ }^{\star}$ M. Konieczkowski, ${ }^{\star}$ and John R. Sedor ${ }^{\ddagger}$ \\ *Department of Medicine, and ${ }^{\ddagger}$ Department of Physiology and Biophysics, School of Medicine, Case Western Reserve University, \\ Cleveland, Ohio 44106; and ${ }^{\S}$ Rammelkamp Center for Research, MetroHealth Medical Center, Cleveland, Ohio 44109
}

\begin{abstract}
Immediate postreceptor events activated by IL-1-IL-1R interaction remain undefined. We have initiated studies to identify candidate signal transducers that associate with the cytosolic domain (cd) of the IL-1R. Immunocomplex kinase assays demonstrated an IL-1-activated myelin basic protein kinase activity that coprecipitated with the IL-1R from rat mesangial, mouse EL-4, and HeLa cells. Using glutathioneS-transferase (GST) fusion proteins, HeLa cell lysates next were assayed for kinases that associated with IL-1R cytoplasmic sequences. A GST-IL-1R fusion protein containing the entire cd (amino acids 369-569; GST-IL-1Rcd) recruited a kinase activity in the absence and presence of IL-1 stimulation. In contrast, a GST-IL-1R membrane-proximal region mutant (amino acids 369-501; GST-IL-1Rcd $\Delta$ ), which lacks $\mathrm{COOH}$-terminal amino acid residues required for nuclear factor $-\kappa \mathrm{B}$ activation, poorly phosphorylated MBP. In gel, kinase assays demonstrated 63-, 83-, and 100kD kinases that specifically coprecipitated with the HeLa IL-1R and the GST-IL-1Rcd, but not GST-IL-1Red $\Delta .{ }^{35} \mathrm{~S}-$ labeled proteins, with $M_{\mathrm{r}} \mathrm{s}$ identical to the kinase activities, stably associated with GST-IL-1Rcd. Transient transfection assays of 293 cells were used to evaluate the functional significance of these findings. Simply increasing IL-1cd expression in 293 cells stimulated 5'-IL-6 flanking region-regulated CAT activity threefold above control, an effect blocked by the kinase inhibitors staurosporine and calphostin C. In summary, we have identified two previously unrecognized 63- and 83-kD kinases as well as a protein with an $M_{\mathrm{r}}$ similar to the recently cloned IL-1R-associated kinase, all of which associate spontaneously with the IL-1Rcd. Ectopic IL-1Rcd expression was sufficient to trigger cellular activation, suggesting that the extracellular domain of the intact receptor represses signal transduction until IL-1 is bound. Given that the IL-1Rcd signaling domain has been conserved in a functionally diverse group of transmembrane receptors, further characterization of this signaling process
\end{abstract}

Parts of this work were presented at the annual meeting of the American Society of Nephrology in New Orleans, LA, 3-6 November 1996.

Address correspondence to John R. Sedor, M.D., Department of Medicine, BG 531A, MetroHealth Medical Center, 2500 MetroHealth Drive, Cleveland, Ohio 44109-1998. Phone: 216-778-4156; FAX: 216-778-8248; E-mail: jrs4@po.cwru.edu

Received for publication 20 December 1996 and accepted in revised form 17 April 1997.

J. Clin. Invest.

(C) The American Society for Clinical Investigation, Inc.

0021-9738/97/07/0419/10 \$2.00

Volume 100, Number 2, July 1997, 419-428 may define novel molecular mechanisms controlling cellular function and differentiation. (J. Clin. Invest. 1997. 100: 419-428.) Key words: cytokines • inflammation • signaling • kinases

\section{Introduction}

Interleukin-1 is a master cytokine that is rapidly synthesized to propagate tissue inflammation (for review see reference 1). Systemic injection of nanogram quantities of IL-1 induces the "acute phase response" (2). Higher concentrations of this cytokine induce hypotension and leukopenia (2), and IL-1 has been implicated in the pathogenesis of septic shock syndrome (3). The synthesis and release of IL-1 within tissues after inflammatory injury has been appreciated only since molecular probes and antibodies became available. Local IL-1 production has been implicated in fibrogenesis, matrix remodeling, and endothelial cell activation that promotes intravascular coagulation and leukocyte adhesion. The discovery of a naturally occurring IL-1 receptor antagonist and soluble, circulating receptors that respectively "block" and buffer IL-1 activity further underscores the phlogistic potential of this cytokine (1). Characterization of the precise signaling pathways activated by the IL-1-IL-1R interaction should provide novel targets for antiinflammatory therapy.

In addition to IL-1 receptor antagonist, the IL-1 peptide family contains two agonist molecules, IL- $1 \alpha$ and IL- $1 \beta$, that bind to the same cell surface receptors. Two distinct IL-1 receptors have been molecularly characterized, an $80-\mathrm{kD}$ (type I) and a $68-\mathrm{kD}$ (type II) receptor. These receptors are highly homologous, each containing three IgG-like extracellular domains and a single transmembrane domain. The $80-\mathrm{kD}$ type I receptor (IL-1RtI) ${ }^{1}$ is present on many cell types, and the 217 amino acid cytoplasmic domain (cd) contains sequences required for activation of cytosolic signaling pathways $(4,5)$. IL1RtI does not contain consensus sequences for either tyrosine or serine/threonine kinase activity or for protein tyrosine kinase phosphorylation acceptor sites. Serine/threonine phosphorylation of the IL-1RtI does occur early after IL-1 binding (6), but the functional importance of this observation remains unclear. Mutagenesis and COOH-terminal deletion of the IL1RtI have delineated a critical region (amino acids 508-529) required for IL-1-induced nuclear factor (NF) $-\kappa \mathrm{B}$ activation and gene expression $(4,5,7,8)$. The type II IL-1R (IL-1RtII) is a $68-\mathrm{kD}$ molecule with a relatively short cytoplasmic tail (29 amino acids) that, in contrast with the extracellular domain,

1. Abbreviations used in this paper: CAT, chloramphenicol acetyltransferase; cd, cytosolic domain; GST, glutathione-S-transferase; IL1R, IL-1 receptor; IL-1RtI, IL-1 type I receptor; IRAK, interleukin-1 receptor-associated kinase; MBP, myelin basic protein; NF, nuclear factor. 
lacks significant homology to the IL-1RtIcd. This receptor is predominantly expressed on leukocytes, functions as a molecular trap for IL-1 to inhibit IL-1 activity, and does not mediate gene activation (9). Studies of a hybrid receptor, composed of the extracellular and transmembrane domains of the IL-1RtII fused to the cd of the IL-1RtI, demonstrate that IL-1-mediated signal transduction is dependent on the presence and activation of the IL-1RtIcd.

Although the binding of IL-1 to the IL-1RtI (hereafter IL$1 \mathrm{R})$ generates lipid-derived signaling molecules and changes in protein phosphorylation state, the most proximate events remain incompletely defined. The cloning of an IL-1R accessory protein, which increases IL-1R binding affinity for IL-1, suggests that the functional IL-1R is a multisubunit complex (10). The finding that IL-1 stimulation recruits to the IL-1R within seconds a putative kinase, IL-1 receptor-associated kinase (IRAK), to activate NF-кB $(8,11)$ further supports this premise. The goal of the present study was to identify candidate signal transducers that specifically associate with the cd of the IL-1R using a glutathione-S-transferase (GST) fusion protein.

\section{Methods}

Cell culture. HeLa and human embryonic kidney 293 cells (American Type Culture Collection, Rockville, MD) were maintained in RPMI 1640 medium (GIBCO BRL, Gaithersburg, MD) supplemented with $2 \mathrm{mM}$ glutamine (GIBCO BRL), $15 \mathrm{mM}$ Hepes, $100 \mathrm{U} /$ $\mathrm{ml}$ penicillin, $100 \mu \mathrm{g} / \mathrm{ml}$ streptomycin, $0.25 \mu \mathrm{g} / \mathrm{ml}$ fungizone, $5 \mu \mathrm{g} / \mathrm{ml}$ insulin and transferrin, $5 \mathrm{ng} / \mathrm{ml}$ sodium selenite, $10 \%$ fetal bovine serum (Hyclone, Logan, UT), and $10 \%$ calf bovine serum (Hyclone) at $37^{\circ} \mathrm{C}$ in $5 \% \mathrm{CO}_{2}$.

Immunoprecipitation and in vitro solution immunocomplex kinase assays. Before initiation of each experiment, cells were held for $3 \mathrm{~h}$ in RPMI medium containing $0.1 \%$ FBS, and then stimulated for $10 \mathrm{~min}$ with vehicle or human recombinant IL- $1 \alpha$ (Hoffman-LaRoche, Nutley, NJ) at a final concentration of $20 \mathrm{ng} / \mathrm{ml}$. In some experiments, HeLa cells were pretreated with $1 \mu \mathrm{M}$ herbimycin, $29 \mu \mathrm{M}$ genistein, $50 \mathrm{nM}$ staurosporine (all from BIOMOL Research Labs., Inc., Plymouth Meeting, PA) or DMSO for $12 \mathrm{~h}$ before stimulation with IL- $1 \alpha$. After washing, the cells were placed on ice and $750 \mu \mathrm{l}$ chilled lysis buffer $\left(\mathrm{Ca}^{2+}\right.$ - and $\mathrm{Mg}^{2+}$-free Dulbecco's phosphate-buffered saline containing $1 \%$ Triton X-100, $5 \mathrm{mM}$ EDTA, $1.2 \mu \mathrm{g} / \mathrm{ml}$ leupeptin, $1.2 \mu \mathrm{g} / \mathrm{ml}$ pepstatin, and $120 \mu \mathrm{M}$ PMSF) was added for $10 \mathrm{~min}$. Extracts were collected and cell debris pelleted by centrifugation at $14,000 \mathrm{~g}$ for $10 \mathrm{~min}$. The resulting supernatants were matched for protein $(600-800 \mu \mathrm{g})$ and sequentially precleared at $4^{\circ} \mathrm{C}$ with nonimmune rabbit $\operatorname{IgG}(1 \mu \mathrm{g})$ for $30 \mathrm{~min}$ and protein A-Sepharose (Pharmacia LKB Biotechnology, Piscataway, NJ) for $1 \mathrm{~h}$. Precleared samples were incubated for $30-60 \mathrm{~min}$ at $4^{\circ} \mathrm{C}$ with $1 \mu \mathrm{g}$ affinity-purified rabbit polyclonal antibody raised against a peptide corresponding to amino acids 550-569 of the IL-1R (Santa Cruz Biotechnology, Inc., Santa Cruz, CA) or an irrelevant, affinity-purified, rabbit polyclonal IgG. To assess specificity, antibodies were incubated in some experiments with either the peptide immunogen (Santa Cruz Biotechnology, Inc.) or bacterially expressed fusion protein containing IL-1Rcd sequences (see below). Protein A Sepharose was subsequently added and the samples were incubated overnight. Protein Aassociated immune complexes were collected by centrifugation in a microfuge for $10 \mathrm{~s}$, washed three times with NET buffer $(150 \mathrm{mM}$ $\mathrm{NaCl}, 5 \mathrm{mM}$ EDTA, $50 \mathrm{mM}$ Tris-HCl, pH 8.0, and $0.05 \% \mathrm{NP}-40$ ), and washed twice with kinase buffer $(100 \mathrm{mM} \mathrm{NaCl}, 20 \mathrm{mM}$ Hepes, $\mathrm{pH}$ $7.0,5 \mathrm{mM} \mathrm{MgCl}_{2}$, and $5 \mathrm{mM} \mathrm{MnCl}$ ). In some experiments, the immune complexes were washed in NET buffer containing either 250 , 500 , or $1,000 \mathrm{mM} \mathrm{NaCl}$. Immunocomplex kinase assays were initiated by resuspending the pellets in $50 \mu l$ kinase buffer supplemented with
$1 \mu \mathrm{M}$ Li-ATP, $5 \mu \mathrm{g}$ myelin basic protein (MBP; Sigma Chemical Co., St. Louis, MO), and $1 \mu \mathrm{Ci}\left[\gamma_{-}{ }^{32} \mathrm{P}\right] \mathrm{ATP}$ (Dupont-NEN, Boston, MA). Reactions proceeded for $10 \mathrm{~min}$ at room temperature and were stopped by adding $15 \mu \mathrm{l} 4 \times$ SDS-Laemmli buffer ( $0.5 \mathrm{M}$ Tris, $\mathrm{pH} 6.8$, $8 \%$ SDS, $40 \%$ glycerol, $0.04 \%$ bromphenol blue, $400 \mu \mathrm{M}$ dithiothreitol). After boiling for $5 \mathrm{~min}$, proteins were analyzed on 12\% SDS-polyacrylamide gels. Radiolabeled proteins were detected by autoradiography. Where indicated, autoradiographic densities were quantified by densitometry and appropriate software as previously published (12).

GST fusion expression constructs. The cd of the IL-1R was amplified from HeLa cell RNA, extracted with Trizol reagent (GIBCO BRL) by reverse transcriptase-PCR (RT-PCR kit; Perkin Elmer Corp., Norwalk, CT) according to the manufacturer's protocols. The following primers $\left(5^{\prime}\right.$ to $\left.3^{\prime}\right)$ : upstream: GGATTCCTGCTATGATT (bp 1436-1453) and downstream: GGATCCGGAGGCACCTAAAGA (bp 2064-2078) amplified a 649-bp fragment that encodes amino acids $369-569$ of the IL-1R, which was isolated from low melting point agarose and cloned into pCRII (Invitrogen Corp., San Diego, CA) by an A-T tailing reaction. Dideoxy sequencing, using a kit (ALF; Pharmacia LKB Biotechnology) according to the manufacturer's protocol, confirmed the sequence fidelity of the amplified IL-1Rcd fragment with the published cDNA sequence. The IL-1Rcd cDNA sequence subsequently was released from pCRII by EcoR1 digestion and subcloned into EcoR1-linearized pGEX4T-1 (Pharmacia LKB Biotechnology) to generate pGEX4T-1-IL-1Rcd. Ligation reactions were used for transformation of DH5 $\alpha$ Escherichia coli, which were selected on LB-ampicillin agar plates. Clones containing the IL-1Rcd cDNA insert in the appropriate orientation were selected by restriction endonuclease mapping. pGEX-4T-1-IL-1Rcd was restricted by $\mathrm{ClaI}$ and SalI to remove IL-1Rcd sequence encoding the COOH-terminal amino acid residues required for NF-кB activation (7). The residual IL-1R sequence consists of a 400-bp fragment encoding membrane proximal region amino acids 369-501. Overhanging ends were filled with Klenow fragment of DNA polymerase I (Boehringer Mannheim, Mannheim, Germany), and then blunt ligated to generate plasmid pGEX-4T-1-IL-1Rcd $\Delta$. The reading frame of the GST-IL-1Rcd junction sequence was confirmed by dideoxy DNA sequencing, and after transformation into BL21 E. coli, both constructs were screened for expression of isopropyl- $\beta$-thiogalactoside (IPTG)-inducible GSTfusion proteins with the predicted $M_{\mathrm{r}}$ (see below).

GST fusion proteins. The expression and purification of the GST fusion proteins was performed as described with modification for purification of insoluble fusion proteins $(13,14)$. BL21 E. coli carrying pGEX4T-1 or the fusion protein expression constructs were grown until the bacterial cultures reached midlogarithmic growth phase $\left(0.4-0.5 \mathrm{~A}_{600}\right)$. ITPG $(0.1 \mathrm{mM})$ was added, and the cultures incubated at $37^{\circ} \mathrm{C}$ for $4 \mathrm{~h}$. The bacteria were collected by centrifugation, the pellets resuspended in STE buffer $(10 \mathrm{mM}$ Tris- $\mathrm{HCl}, \mathrm{pH} 8.0,150 \mathrm{mM}$ $\mathrm{NaCl}, 2 \mathrm{mM}$ EDTA, $1 \mathrm{mM}$ PMSF, $2 \mathrm{mg} / \mathrm{ml}$ pepstatin, and $2 \mathrm{mg} / \mathrm{ml} \mathrm{leu-}$ peptin), and the bacteria lysed by incubation with $0.3 \mathrm{mg} / \mathrm{ml} \mathrm{lysozyme}$ at $4^{\circ} \mathrm{C}$ for $15 \mathrm{~min}$, followed by the addition of $5 \mathrm{mM}$ DTT and $1.5 \%$ $N$-laurylsarcosine (sarkosyl) to recover GST-IL-1Rcd and GSTIL-1Rcd $\Delta$ fusion proteins. Sarkosyl was not required for recovery of GST. The bacteria were disrupted by brief sonication on ice, and the lysate clarified at $4^{\circ} \mathrm{C}$ by centrifugation at $1,000 \mathrm{~g}$ for $15 \mathrm{~min}$. Each supernatant was incubated at $4^{\circ} \mathrm{C}$ for $2 \mathrm{~h}$ with $700 \mu \mathrm{l} \mathrm{GSH}$-Sepharose (Pharmacia LKB Biotechnology). The Sepharose matrix was recovered by centrifugation and washed four times with STE buffer containing $0.1 \%$ Triton $\mathrm{X}-100$ and stored at $4^{\circ} \mathrm{C}$ as a $35 \%$ slurry in STE buffer containing $0.1 \%$ Triton X-100, $5 \mathrm{mM}$ DTT, and $10 \%$ glycerol. For some experiments, GST fusion proteins and GST were eluted from the GSH-Sepharose matrix as described (13), and free GSH was removed using Sephadex G-25 columns. GST fusion and GST protein integrity was analyzed on Coomassie blue-stained SDS-polyacrylamide gels, and protein concentration estimated by comparison with known concentrations of bovine serum albumin.

Fusion protein solution kinase and binding assays. HeLa cells were held for $3 \mathrm{~h}$ in RPMI media supplemented with $0.1 \%$ FBS before 
stimulation for $10 \mathrm{~min}$ with $20 \mathrm{ng} / \mathrm{ml}$ of recombinant IL- $1 \alpha$. Cell extracts, prepared as described above, were precleared with $25 \mu \mathrm{g}$ equine GST and GSH-Sepharose for $2 \mathrm{~h}$ at $4^{\circ} \mathrm{C}$. Sepharose matrix was removed by centrifugation, and the resulting cell supernatants were incubated overnight at $4^{\circ} \mathrm{C}$ with 5-10 $\mu \mathrm{g}$ GST, GST-IL-1Rcd, or GST-IL-1Rcd $\Delta$ proteins. The beads were collected by centrifugation and washed three times with NET buffer and twice with kinase buffer. Where indicated, pellets were washed in NET buffer containing either 250,500 , or $1,000 \mathrm{mM} \mathrm{NaCl}$. Pellets were then used in in vitro solution kinase assays as described above.

For binding assays, HeLa cells were serum deprived for $1 \mathrm{~h}$ in cysteine- and methionine-free RPMI medium (ICN Biomedicals Inc., Irvine, CA), supplemented with $0.1 \%$ fetal bovine serum for $1 \mathrm{~h}$, washed once, and incubated for $18 \mathrm{~h}$ in cysteine- and methionine-free RPMI medium, supplemented with $10 \%$ complete RPMI medium and $18 \mu \mathrm{Ci} / \mathrm{ml}\left[{ }^{35} \mathrm{~S}\right]$ translabel (ICN Biomedicals Inc.). In some experiments, labeled cells were treated with $20 \mathrm{ng} / \mathrm{ml} \mathrm{IL-1} \alpha$ for the final 10 min. Cell extracts were prepared as previously described, precleared with equine glutathione-S-transferase and GSH-Sepharose, and incubated with GST or the GST fusion protein as described above. Beads were collected, washed five times with NET buffer containing 150, 250,500 , or $1,000 \mathrm{mM} \mathrm{NaCl}$, and boiled for 5 min with $50 \mu \mathrm{l}$ of $4 \times$ SDS-Laemmli loading buffer. Proteins were resolved on $10 \%$ SDSpolyacrylamide gels, and labeled proteins were visualized by fluorography (ENHANCE; DuPont NEN).

Solid phase (in-gel) kinase assays. Solid phase kinase assays were performed as described previously $(15,16)$. Briefly, proteins immunoprecipitated by nonspecific antibody, anti-IL-1R antibody, GST, or the GST fusion proteins, which had been incubated with clarified cell extracts as described above, were resolved on $10 \%$ SDS-polyacrylamide gels copolymerized with $0.1 \mu \mathrm{g} / \mathrm{ml}$ MBP. After electrophoresis, SDS was removed from the gel by soaking twice for $20 \mathrm{~min}$ in buffer A (20\% isopropanol, $50 \mathrm{mM}$ Tris, $\mathrm{pH}$ 7.4, $1 \mathrm{mM}$ EGTA, $1 \mathrm{mM}$ DTT) and by rinsing twice in buffer $\mathrm{B}(50 \mathrm{mM}$ Tris, $\mathrm{pH} 7.4,1 \mathrm{mM}$ EGTA, $1 \mathrm{mM}$ DTT, $50 \mathrm{mM} \mathrm{NaCl}$ ). Proteins were denatured by serially incubating the gel for $40 \mathrm{~min}$ each in $9,6,3,1.5$, and $0.75 \mathrm{M}$ urea in buffer $\mathrm{B}$, and then renatured in buffer $\mathrm{C}(25 \mathrm{mM}$ Hepes, $\mathrm{pH} 7.3,1 \mathrm{mM}$ EGTA, $1 \mathrm{mM}$ DTT, $5 \mathrm{mM} \mathrm{MgCl} 2,0.04 \%$ Tween 20 ) at $4^{\circ} \mathrm{C}$ for $16-18 \mathrm{~h}$ with five buffer changes. Subsequently, the gel was incubated for $30 \mathrm{~min}$ in $30 \mathrm{ml}$ of kinase buffer $(20 \mathrm{mM}$ Hepes, $\mathrm{pH} 7.3,50 \mathrm{mM} \beta$-glycerol phosphate, $\mathrm{pH} 7.3,20 \mathrm{mM} \mathrm{MgCl} 2,1.5 \mathrm{mM}$ EGTA, $1 \mathrm{mM}$ DTT, $0.03 \%$ Brij35) at $33^{\circ} \mathrm{C}$. Then, the kinase reaction was initiated by incubating the gel in $30 \mathrm{ml}$ of kinase buffer containing $300 \mu \mathrm{Ci}$ of $\left[\gamma^{-32} \mathrm{P}\right] \mathrm{ATP}$ and $20 \mu \mathrm{M}$ ATP for $2 \mathrm{~h}$ at $33^{\circ} \mathrm{C}$. The gel was then washed extensively with buffer D (5\% [vol/vol] trichloroacetic acid and 5\% [wt/vol] sodium pyrophosphate) until radioactivity contained in the washes was negligible.

Eukaryotic expression constructs, transient transfection, and CAT assays. An IL-1Rcd eukaryotic expression construct was synthesized by subcloning IL-1Rcd sequences, described above, into a HindIIIlinearized episomal vector pEBVHisB (Invitrogen Corp.) to generate pEBVHisBIL-1Rcd. The control plasmid pEBVHisLacZ was purchased from Invitrogen Corp. The human IL-6 5'-flanking region $(-742$ to +11$)$ fused to the chloramphenicol acetyltransferase (CAT) gene (17) was a generous gift from Dr. Jan Vilcek (New York University Medical Center, New York). Wild-type human embryonic kidney 293 cells and 293 cells stably expressing the EBNA-1 protein (293EBNA; Invitrogen Corp.) were grown in Dulbecco's modified Eagle's medium supplemented with $10 \%$ FBS, $100 \mathrm{U} / \mathrm{ml}$ penicillin $\mathrm{G}$, $100 \mu \mathrm{g} / \mathrm{ml}$ streptomycin, and $0.25 \mu \mathrm{g} / \mathrm{ml}$ fungizone. 293-EBNA cells were selected with geneticin $(250 \mu \mathrm{g} / \mathrm{ml}$; Life Technologies, Inc., Grand Island, NY). Before transfection, cells $\left(5 \times 10^{5}\right)$ were seeded in 100-mm dishes. The indicated expression constructs $(10 \mu \mathrm{g}$ each $)$ were transfected, using calcium phosphate coprecipitation (14), 24 or $48 \mathrm{~h}$ after plating for the 293 and 293-EBNA cells, respectively. The following day, medium was replaced with DMEM containing $2 \%$ FBS and, after a subsequent $24 \mathrm{~h}$ in $0.1 \%$ FBS, cells were stimulated with recombinant IL-1 $\alpha(20 \mathrm{ng} / \mathrm{ml})$ or vehicle. In some experiments, protein kinase inhibitors, as indicated, were included for the final $24 \mathrm{~h}$ in the absence or presence of IL-1 $\alpha$. Cells were harvested $72 \mathrm{~h}$ after transfection and CAT activity in cell extracts was determined by liquid scintillation quantification of $\left[{ }^{14} \mathrm{C}\right] n$-butyryl chloramphenicol, as described (14). Preliminary experiments demonstrated that the radioactivity contained in these extracts exclusively represented acetylated chloramphenicol. CAT activities were normalized for cell lysate protein content, determined by the BCA method (Pierce Chemical Co., Rockford, IL).

\section{Results}

$I L-1 R$ coprecipitates with a protein kinase from IL-1-activated cells. IL-1-activated gene transcription has been demonstrated in HeLa cells $(17,18)$, and we demonstrated HeLa cell IL-1R expression using reverse transcriptase-PCR (data not shown). Immunoprecipitates from IL- $1 \alpha-$ and vehicle-stimulated HeLa cells were assayed for kinase activity using MBP as an exogenous substrate as described in Methods. Substantial MBP kinase activity coprecipitated with specific, but not control, antibody from cells treated with IL-1 (Fig. $1 A$ ). IL-1R immunocomplexes from vehicle-treated cells did phosphorylate MBP in this particular experiment (Fig. $1 A$, lane 3). However, this finding was inconsistent. Importantly, simply increasing the $\mathrm{NaCl}$ concentration in the washes substantially reduced the kinase activity associated with IL-1R immunocomplexes derived from vehicle-stimulated cells (not shown), demonstrating relatively weak and nonspecific, protein-protein interactions. In contrast, the MBP kinase activity, coprecipitating with IL-1R immunocomplexes from IL-1-stimulated cells, changed little even after washing the precipitates with salt concentrations as high as $1 \mathrm{M}$ (not shown). The minimal MBP kinase activity associated with control antibodies (Fig. $1 A$, lanes 1 and 2) was variable between experiments and eliminated by increases in salt concentrations in the wash buffers. The lack of consistent MBP kinase activity associated with IL-1R immunocomplexes derived from vehicle-treated cells suggests that kinase activity is not an intrinsic property of the IL-1R, although the anti-IL-1R antibody used in these experiments could block intrinsic IL-1R kinase activity within the cd. However, IL-1R immunoprecipitates from vehicle-treated cells, obtained with an antipeptide antibody directed against epitopes in the extracellular domain of the IL-1R, also failed to phosphorylate MBP (not shown). IL-1R immunocomplexes from IL-1-stimulated cells reproducibly coprecipitated cellular phosphoproteins of apparent 63, 83, and $100 \mathrm{kD}$, which may be endogenous MBP kinase substrates (Fig. $1 A$, lane 4 ). IL-1 rapidly activated the MBP kinase coprecipitable with the IL-1R (Fig. $1 B$ ). Phosphorylation of MBP and the putative endogenous cellular substrates was detectable after $1 \mathrm{~min}$, had doubled by $3 \mathrm{~min}$, plateaued by $5 \mathrm{~min}$, and persisted for at least $10 \mathrm{~min}$. The higher molecular phosphoproteins, detected by autoradiography for $20 \mathrm{~h}$ (Fig. 1 $A$ ), are not visualized in these 2-h autoradiograms. MBP kinase activity also coprecipitated with the IL-1R from EL-4 and glomerular mesangial cells, demonstrating that these observations were not unique to HeLa cells. Taken together, these data suggest that the ligation of the IL-1R by IL-1 rapidly recruits or activates a constitutively associated kinase activity.

Genistein, herbimycin, or staurosporine did not substantially inhibit association/activation of the MBP kinase coprecipitable with $I L-1 R$. We next determined if a posttranslational phosphorylation regulated the association/activity of the MBP 
A

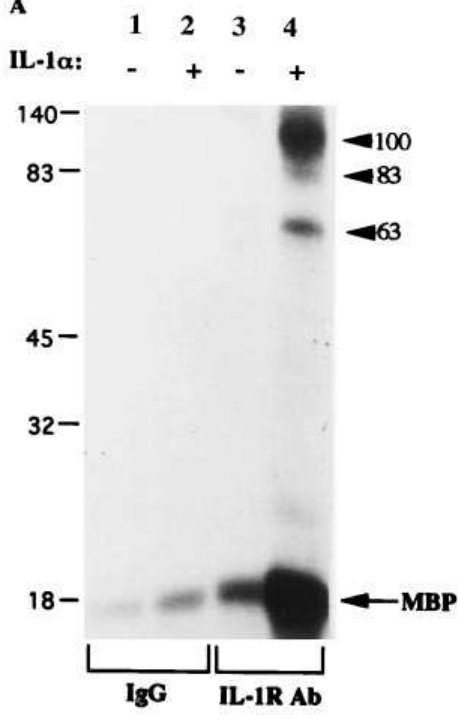

B

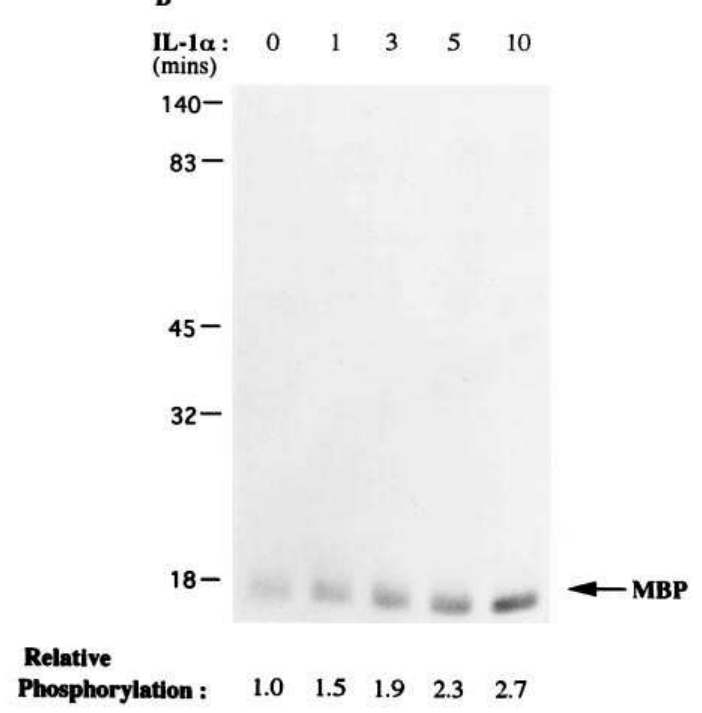

Figure 1. The IL-1R specifically coprecipitates with a protein kinase(s) that phosphorylates myelin basic protein. $(A)$ HeLa cells were held in RPMI medium supplemented with $0.1 \%$ fetal bovine serum for $3 \mathrm{~h}$. The cells were then stimulated with $(+)$ or without $(-)$ IL-1 $\alpha(20 \mathrm{ng} / \mathrm{ml})$ for $10 \mathrm{~min}$, and IL-1R was immunoprecipitated using a polyclonal antiIL-1R antipeptide antibody $(I L-1 R A b)$ or nonspecific rabbit $\operatorname{IgG}(\operatorname{Ig} G)$. Immunocomplexes were assayed for kinase activity as described in Methods, using myelin basic protein $(M B P)$ as an exogenous substrate. Proteins were resolved on a $12 \%$ SDS-polyacrylamide gel and migration of MBP was confirmed by Coomassie blue staining. ${ }^{32} \mathrm{P}$-labeled products were detected by autoradiography for $20 \mathrm{~h}$ to identify endogenous substrates

that coprecipitate with the IL-1R. Molecular mass markers (in kilodaltons) are indicated at left. $(B)$ HeLa cells were stimulated for the indicated times (left) and solution kinase assays performed. Relative changes in MBP phosphorylation, quantified by scanning densitometry, are indicated. Autoradiography was $2 \mathrm{~h}$.

kinase coprecipitable with IL-1R. IL-1 induces serine/threonine phosphorylation and tyrosine phosphorylation of a number of cellular substrates, including the murine IL-1R, and both human and murine IL-1R contain a putative $\mathrm{C}$ - and A-kinase acceptor site (6). These later data suggested to us that a change in either MBP kinase or IL-1R phosphorylation states may be required for MBP kinase association/activation. To test this hypothesis in these experiments, HeLa cells were preincubated with the indicated kinase inhibitors (see Methods and Fig. 2) and subsequently stimulated with IL-1 for $10 \mathrm{~min}$. IL-1R immunocomplexes were washed to remove residual inhibitor and assayed for kinase activity. The inhibitor concentrations employed in these experiments have been used previously to block kinase activity. Pretreatment of HeLa cells with the tyrosine kinase inhibitors, genistein and herbimycin, or the serine/threonine-kinase inhibitor staurosporine failed to inhibit significantly IL-1-stimulated coprecipitation of the MBP kinase with the IL-1R (Fig. 2). MBP phosphorylation was similar in IL-1-treated cells in the absence or presence of the kinase inhibitors or their vehicle (DMSO). Densitometric analysis of the experiment shown in Fig. 2 and two similar experiments confirmed that none of the kinase inhibitors significantly reduced IL-1-activated MBP phosphorylation (relative MBP phosphorylation, mean \pm SEM, $n=3$ : IL-1, 1 ; IL-1 + genistein, 0.95 \pm 0.04 ; IL-1 + herbimycin, 0.93 \pm 0.09 ; IL-1 + staurosporine, $0.99 \pm 0.1$ ) or the 83 - or $100-\mathrm{kD}$ phosphoproteins (not shown). Pretreatment of HeLa cells with herbimycin did variably reduce association of the $63-\mathrm{kD}$ phosphoprotein with IL-1R immunocomplexes, a finding that did not significantly reduce the aggregate level of MBP phosphorylation (relative $63-\mathrm{kD}$ phosphorylation; mean \pm SEM, $n=3$ : IL-1, 1 ; IL-1 + herbimycin, 61.1 \pm 20.6$)$. These results suggest that IL1R-MBP kinase association and kinase activation does not depend substantially on protein phosphorylation.
A GST-IL-1R fusion protein containing IL-1Rcd sequences can recruit MBP kinase activity from HeLa cell extracts. We next used GST fusion proteins to assay cell lysates for kinases associated with IL-1R intracellular sequences. Fig. 3 shows the fusion protein constructs. GST-IL-1Rcd contains IL-1Rcd sequences $\mathrm{COOH}$ terminal to the transmembrane region (amino acids 369-569). GST-IL-1Rcd $\Delta$ contains the membrane proximal region of the IL-1Rcd (amino acids 369501), lacking the COOH-terminal amino acid residues required for NF-кB activation (7). Bacterially expressed GST and the GST-IL-1R fusion proteins were incubated with Triton X-100 HeLa cell extracts and used in the solution kinase assay as described in Methods. Consistent with the data obtained with HeLa IL-1R immunocomplexes, GST-IL-1Rcd associated with MBP kinase activity (Fig. 4). GST-IL-1R also autophosphorylated and, similar to IL-1R immunocomplexes, labeled putative cellular substrates of apparent $M_{\mathrm{r}} 63$ and 100 $\mathrm{kD}$. The $83-\mathrm{kD}$ protein labeled by IL-1R immunocomplexes is not seen in this experiment, although a $31-\mathrm{kD}$ cellular phosphoprotein coprecipitated with GST-IL-1Rcd. In contrast, GSTIL-1Rcd $\Delta$ poorly phosphorylated MBP (Fig. 4), did not autophosphorylate, and failed to coprecipitate with any cellular phosphoproteins. Washing the GST-IL-1R cellular protein complexes with increasing salt concentrations produced results in agreement with the data obtained with IL-1R immunocomplexes. MBP kinase activity stably associated with GST-IL-1Rcd, but not GST-IL-1Rcd $\Delta$, even after washes with salt concentrations up to $1 \mathrm{M}$ (not shown), suggesting that the kinase activity recruited by a kinase-binding domain (within amino acids 501569 ) is functionally important in initiating IL-1-activated downstream signaling events. Minimal kinase activity was precipitated by GST bound to glutathione agarose (Fig. 4). Control experiments demonstrated that the kinase activity originated from cellular extracts. No phosphorylation of MBP was 


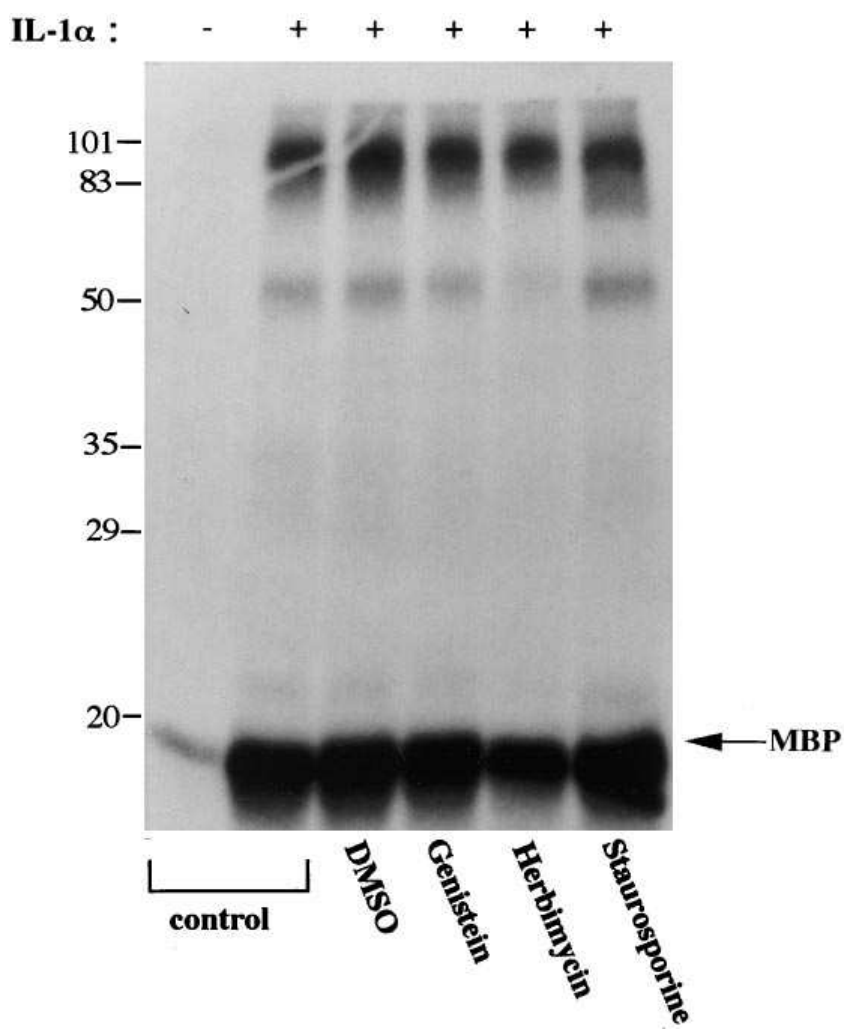

Figure 2. The kinase inhibitors, genistein, herbimycin, or staurosporine, do not prevent association/activation of MBP kinase(s) with the IL-1R. HeLa cells were incubated in the absence (control) or presence of herbimycin $(1 \mu \mathrm{M})$, genistein $(29 \mu \mathrm{M})$, staurosporine (50 $\mathrm{nM})$, and DMSO (vehicle-control) for $12 \mathrm{~h}$ before stimulation with $(+)$ or without (-) IL-1 $\alpha(20 \mathrm{ng} / \mathrm{ml})$ for $10 \mathrm{~min}$. IL-1R was immunoprecipitated with an anti-IL-1R antibody, and after washing to remove residual inhibitor, the immunocomplexes were assayed for kinase activity as described in Methods. Proteins were resolved on $12 \%$ SDS polyacrylamide gels, and phosphorylated proteins were visualized by autoradiography as described in Fig. 1. The migration of MBP, confirmed by Coomassie staining, is shown on the right and molecular mass markers (in kilodaltons) are indicated at left.

seen in the absence of HeLa cell lysates (not shown), further suggesting that the IL-1Rcd itself has no intrinsic kinase activity. Interestingly, coprecipitation of GST-IL-1Rcd and the MBP kinase activity did not require IL-1 treatment of HeLa cells before lysis (Fig. 4), indicating that IL-1cd sequences contain the structural information to associate constitutively with cytosolic signaling proteins. To investigate the subcellular localization of the IL-1R-associated MBP kinase activity, HeLa cytosolic and membrane fractions, prepared from lysates obtained by Dounce homogenization, were used in solution kinase assays with GST-IL-1Rcd. IL-1R-associated MBP kinase activity was identified in the cytosolic fraction (not shown).

Solid phase (in-gel) kinase assays demonstrate MBP kinase activities with apparent 63, 83, and 100 kD. Protein kinases, present in extracts of HeLa cells treated with IL-1 $\alpha$ and coprecipitated with IL-1cd sequences, were next analyzed after SDSpolyacrylamide gel electrophoresis through the use of a solid phase (in-gel) assay with MBP polymerized in the gel (Fig. 5). Treatment with IL- $1 \alpha$ increased phosphorylation of MBP by
A. IL-IR I :

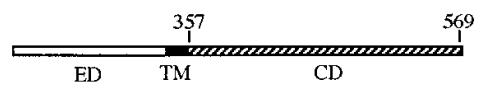

B. FUSION PROTEIN CONSTRUCTS :

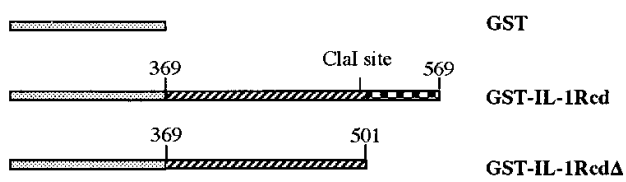

Figure 3. GST-IL-1Rcd fusion proteins. A series of GST fusion proteins were purified from $E$. coli as described in Methods. ( $A$ ) The full length 569 amino acid human IL-1R is shown for reference (30). The mature transmembrane protein is 552 amino acids. The extracellular domain (open region, ED), including a 17 amino acid signal peptide, spans from amino acids 1 to 336, the transmembrane region (solid region, TM) from 337 to 357, and the cytosolic domain (hatched region, $C D$ ) from 358 to 569 . (B) GST and the GST-IL-1R fusion proteins are shown. GST-IL-1Rcd contains the amino acids 369-569 of the IL-1Rcd fused to GST (stippled region). The ClaI site in the IL-1Rcd cDNA sequence, used to remove the sequences encoding the $\mathrm{COOH}$ terminal amino acid residues required for NF- $\mathrm{kB}$ activation (7), is indicated. The resulting fusion protein, GST-IL-1Rcd $\Delta$, contains membrane proximal cd region amino acids 369-501 fused to GST.

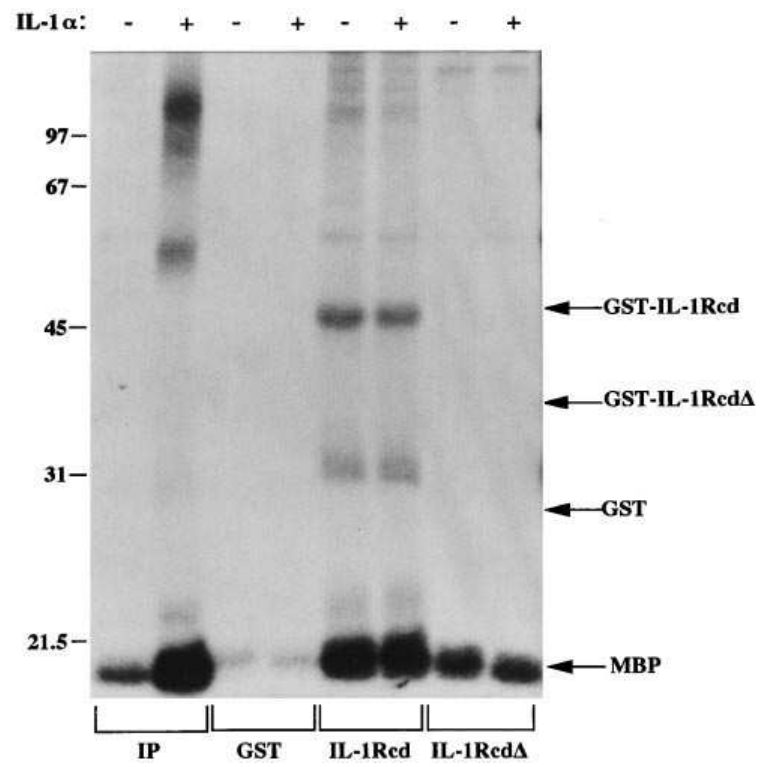

Figure 4. A GST-fusion protein containing IL-1Rcd sequences associates with MBP kinase activity from HeLa cells. Extracts, prepared from HeLa cells held in RPMI media supplemented with $0.1 \%$ FBS for $3 \mathrm{~h}$ before stimulation with (+) or without (-) IL-1 $\alpha(20 \mathrm{ng} / \mathrm{ml})$ for $10 \mathrm{~min}$, were incubated with GST or the GST-IL-1R fusion proteins and assayed for MBP kinase activity as described in Methods. HeLa IL-1R immunocomplexes $(I P)$ were also assayed for kinase activity. Proteins were analyzed by SDS-PAGE and phosphorylated proteins were visualized as described in Fig. 1. The migration of GST and the GST-IL-1R fusion proteins, confirmed by Coomassie staining, is shown on the right, and molecular mass markers (in kilodaltons) are indicated at left. 


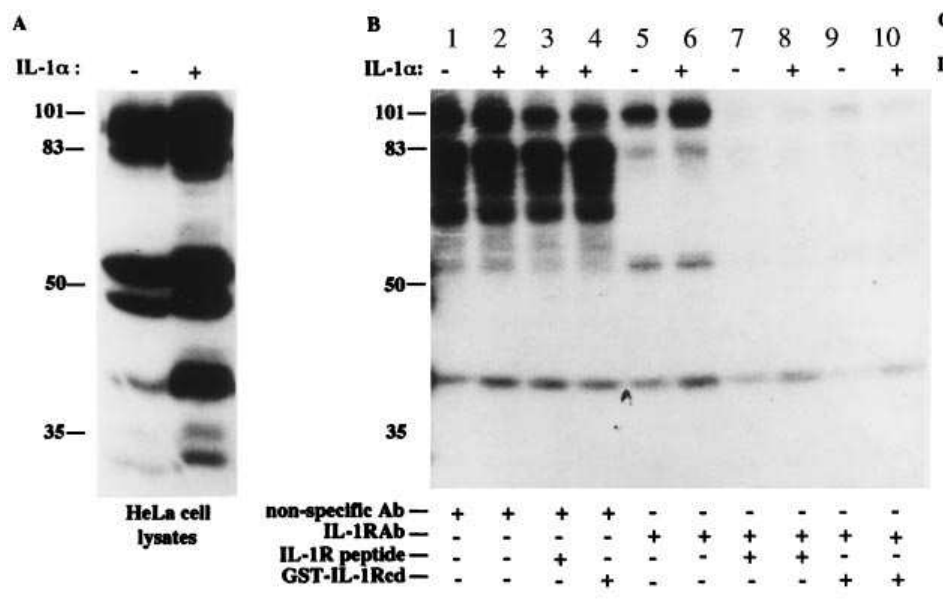

c

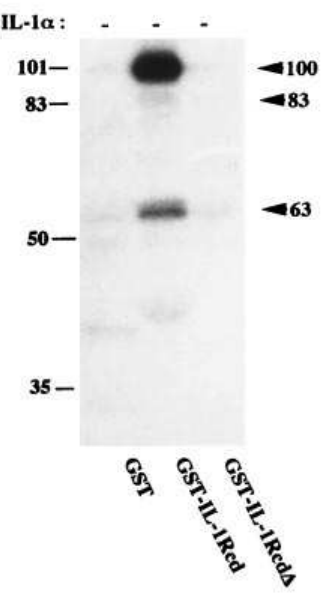

Figure 5. Solid phase (in-gel) kinase assays demonstrate 63-, 83-, and 100-kD MBP kinases specifically coprecipitate with IL-1R immunocomplexes and GST-IL-1Rcd. HeLa cells were held in RPMI media supplemented with $0.1 \%$ FBS for $3 \mathrm{~h}$, and then stimulated with (+) or without (-) IL-1 $\alpha(20 \mathrm{ng} / \mathrm{ml})$ for $10 \mathrm{~min}$. Protein kinases in cell lysates were analyzed after $10 \%$

SDS-PAGE using gels polymerized with $0.1 \mu \mathrm{g} / \mathrm{ml} \mathrm{MBP}$ as described in Methods. Phosphorylated MBP was visualized by autoradiography. Molecular mass markers (in kilodaltons) are indicated at left. ( $A$ ) IL-1 $\alpha$ stimulates the activity of multiple MBP kinases in Triton X-100 HeLa cell extracts. (B) MBP kinases associated with immunoprecipitates of HeLa cell extracts, obtained using a nonspecific (lanes 1-4) or anti-IL-1R antibody (IL-1RAb). Competition coprecipitation experiments (lanes 3-4 and 7-10) were performed by incubating the precipitating antibody with the IL-1R peptide epitope (IL-1R peptide; lanes 3, 7, and 8) or with GST-IL-1Rcd (lanes 4, 9, and 10). (C) MBP kinases associate specifically with GST-IL-1Rcd, but not GST-IL-1Rcd $\Delta$ or GST. Molecular masses (in kilodaltons) of associating MBP kinases are indicated on right. Kinases with similar $M_{\mathrm{r}}$ specifically associate with IL-1R immunocomplexes $(B)$.

protein kinases of 100,83 , and $63 \mathrm{kD}$, proteins with apparent molecular weights identical to the putative endogenous cellular MBP kinase substrates previously observed identified in Fig. $1 A$ (Fig. $5 A$ ). Other MBP kinases with lower apparent molecular weights $(48,40$, and $35 \mathrm{kD})$ were also detected. These results confirm that IL-1 rapidly increases activities of multiple intracellular kinases.

In Fig. $5 B$, immunoprecipitates of HeLa cell extracts, obtained using a nonspecific (Fig. $5 B$, lanes $1-4$ ) and anti-IL-1R antibodies (Fig. 5 B, lanes 5-10), were analyzed for coprecipitating MBP kinase activity. MBP kinases of $\sim 63,83$, and 100 $\mathrm{kD}$ specifically precipitate with the IL-1R from HeLa cells treated with either IL-1 $\alpha$ (Fig. $5 B$, lane 6 ) or vehicle (Fig. $5 B$, lane 5). Competition coprecipitation experiments were performed with anti-IL-1R antibody and either the IL-1R-peptide immunogen or the GST-IL-1R fusion protein using extracts from vehicle control or IL-1-treated cells (Fig. 5 B, lanes $7-10)$. Both the competitors prevented the precipitation of the kinase activities. In contrast, the pattern of MBP kinase activities coprecipitating with irrelevant antibody (Fig. 5 B, lanes 1 and 2) was unchanged in parallel competition coprecipitation experiments (Fig. $5 \mathrm{~B}$, lanes 3 and 4 ), indicating that MBP kinase activities coprecipitated by irrelevant antibody differ from those associating with the IL-1R. In contrast with the data obtained using solution immunocomplex kinase assays, the MBP kinase activities, which specifically coprecipitated with the IL-1R (Fig. 5 B, lanes 5 and 6 ), were not regulated strongly by IL- $1 \alpha$.

MBP kinases that coprecipitated with the GST-IL-1R fusion proteins were also analyzed in gel (Fig. $6 C$ ). GST-IL-1Rcd precipitated from HeLa cell extracts MBP kinases with $M_{\mathrm{r}}$ identical to those kinase activities, which coprecipitated with the wild-type IL-1R $(63,83$, and $100 \mathrm{kD})$. The 83-kD kinase activity obtained using specific antibody was more abundant than that recruited by the fusion protein. Neither GST or GST-IL-1Rcd $\Delta$ coprecipitated these kinase activities. This correlation between the inability of IL-1Rcd $\Delta$ to activate NF$\kappa \mathrm{B}(7)$ and the coprecipitation results obtained with GSTIL-1Rcd and GST-IL-1Rcd $\Delta$ suggests that MBP kinases of 63, 83 , and $100 \mathrm{kD}$ are involved in IL-1R signaling.

GST-IL-1R cytosolic domain fusion proteins specifically associate with ${ }^{35}$ S-labeled proteins from HeLa cell extracts. The GST-IL-1R fusion proteins and GST were incubated with lysates from ${ }^{35} \mathrm{~S}$-labeled HeLa cells (Fig. 6). Bands, found to coprecipitate specifically with the GST-IL-1Rcd (Fig. 6) and with IL-1R immunocomplexes (not shown), were similar in size to the MBP kinase activities $(63,83$, and $100 \mathrm{kD})$ that coprecipitated with this fusion protein and the IL-1R. In addition, other $\left[{ }^{35} \mathrm{~S}\right]$ proteins specifically associate with both GSTIL-1Rcd and GST-IL-1Rcd $\Delta$. The association of the $\left[{ }^{35} \mathrm{~S}\right]$ 63-, 83-, and 100-kD proteins with GST-IL-1Rcd or with IL-1R immunocomplexes was not altered by stimulating the cells for 10 min with IL-1 $\alpha$ before lysis (data not shown), further indicating that these proteins constitutively associated with cd sequences. To assess the strength of the cellular protein interactions with the GST-IL-1Rcd fusion protein, the GST-IL-1R HeLa cell protein complexes were washed with increasing salt concentrations. The p63, p83, and p100 remained associated with GST-IL-1Rcd, but not either GST-IL-1Rcd $\Delta$ or GST over a range of salt concentrations from $150 \mathrm{mM}$ to $1 \mathrm{M}$ (Fig. 6, $A$ and $B$, black arrowheads). A $35-\mathrm{kD}$ protein also specifically associates with the GST-IL-1Rcd, which is somewhat more sensitive to high salt since its association with the fusion protein diminishes in $500 \mathrm{mM} \mathrm{NaCl}$ and is eliminated in $1 \mathrm{M}$ $\mathrm{NaCl}$ (Fig. 6, $A$ and $B$ ). In addition, several other ${ }^{35} \mathrm{~S}$-labeled proteins specifically associated with both GST-IL-1R fusion proteins, even in high $\mathrm{NaCl}$ (Fig. $6 \mathrm{~B}$, open arrowheads), suggesting that other signaling molecules may associate with the membrane proximal domain of the IL-1R.

Transient transfection of an IL-1Rcd eukaryotic construct activates IL-6 gene transcription. To evaluate the functional significance of molecules that associate with the IL-1Rcd, we 

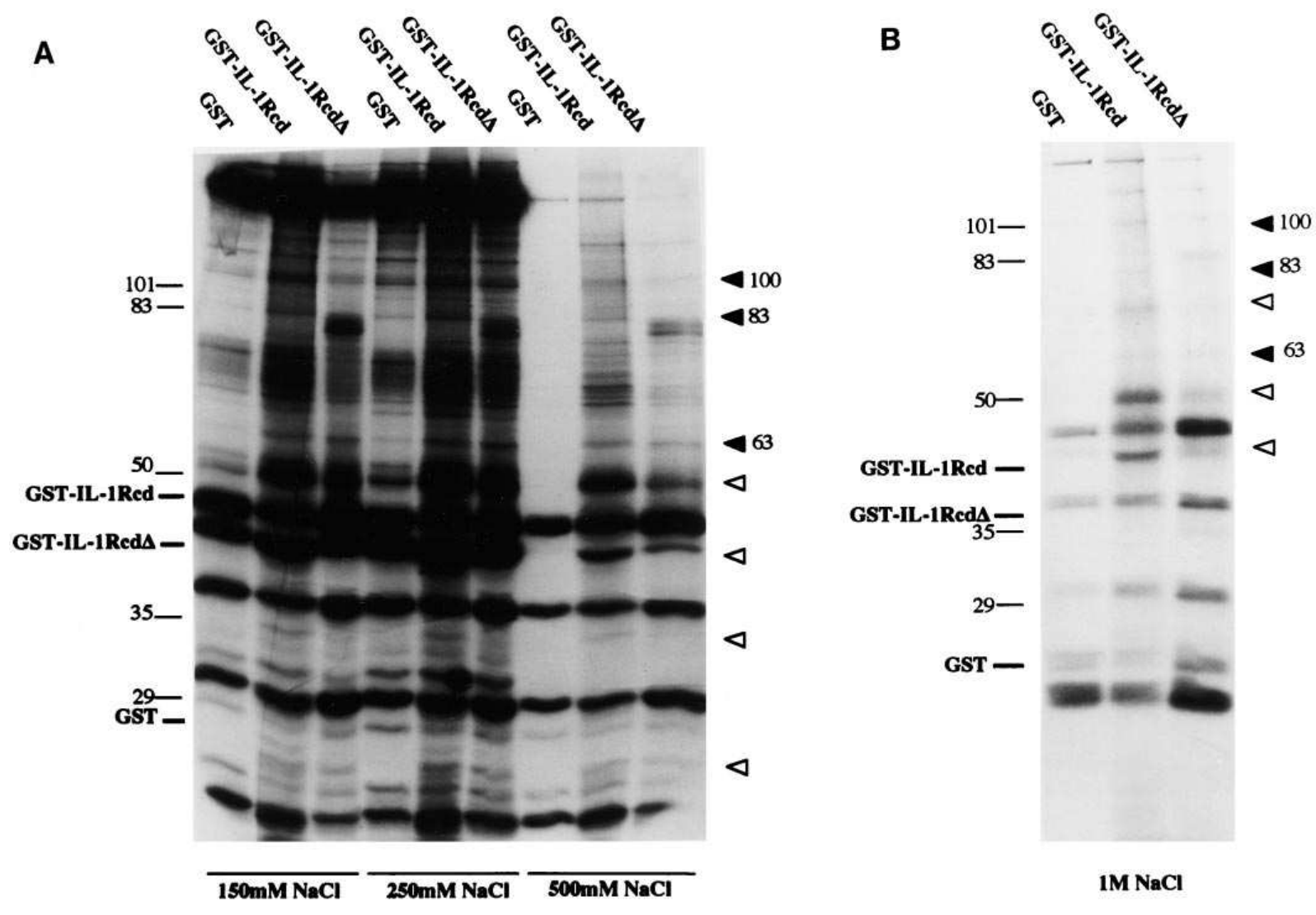

Figure 6. Metabolically labeled cellular proteins associate with GST-IL-1R fusion proteins even after high salt washes. ${ }^{35} \mathrm{~S}$-labeled cell extracts were prepared, precleared, and incubated overnight with GST, GST-IL-1Rcd, and GST-IL-1Rcd $\Delta$ as described in Methods. The beads were collected and washed repeatedly with buffers containing $(A) 150,250$, or $500 \mathrm{mM}$, or $(B) 1 \mathrm{M} \mathrm{NaCl}$. GST and the GST-IL-1R fusion proteins and associated cellular proteins were analyzed by $10 \%$ SDS-PAGE and fluorography. The migration of GST and the GST-IL-1R fusion proteins, confirmed by Coomassie staining, and molecular mass markers (in kilodaltons) are indicated at left. Solid arrowheads indicate ${ }^{35} \mathrm{~S}-$ labeled proteins with 63,83 , and $100 \mathrm{kD}$. Open arrowheads indicate other ${ }^{35} \mathrm{~S}$-labeled proteins specifically associated with the GST-IL-1R fusion proteins.

next assessed the effects of IL-1Rcd expression on IL-6 transcription by cotransfecting a CAT reporter gene under control of IL-6 5'-flanking sequences (bp -742 to +11$)$ and an episomal EBV expression construct containing the IL-1cd sequences contained in GST-IL-1Rcd (EBV-HisIL-1R or "Rcd" [Fig. 7]) or a control vector (EBV-HisLacZ or "GAL" [Fig. 7]). In addition, another EBV expression vector (pEBV-HisBIL-1Rkb or "Rkb" [Shirvaikar, A., R. Singh, K. Schaeffer, M. Konieczkowski, and J.R. Sedor, manuscript in preparation]), containing only the COOH-terminal IL-1Rcd sequences (bp 501-569) known to be critical for productive downstream signaling $(4,5,7,8)$, was used in these studies. The amino acids encoded by this $\mathrm{COOH}$-terminal IL-1Rcd sequence recruit MBP kinase activity and specifically associate with MBP kinases with 63, 83, and $100 \mathrm{kD}$ (data not shown; Shirvaikar, A., R. Singh, K. Schaeffer, M. Konieczkowski, and J.R. Sedor, manuscript in preparation). Our in vitro data predicted that, even in the absence of IL- $1 \alpha$ stimulation, IL-1Rcd sequences would recruit active MBP kinases to stimulate IL-6regulated CAT activity. Therefore, we chose the highly transfectable 293 cell line, which minimally expresses the IL-1R (7). Both wild-type 293 and 293-EBNA cells were used. CAT activity in transiently transfected cells was measured in the pres- ence and absence of IL- $1 \alpha$. A low level of CAT activity was measurable in 293-EBNA cells transfected with a control expression construct containing the $\beta$-galactosidase gene (Fig. 7). In the absence of ectopic cd, IL-1 $\alpha$ minimally induced transcriptional activation through endogenous IL-1R. In contrast, a 2.5-4-fold increase in IL-6 5' -flanking region-regulated transcription was measured in untreated 293-EBNA cells transiently transfected with IL-1Rcd expression constructs (Fig. 7). The observed increase in CAT activity is similar to that reported in IL-1-responsive cells transfected with this IL-6 reporter chimera (17). These data demonstrate in whole cells that the protein associations with the IL-1Rcd sequences have functional consequences. In addition, Rcd and Rkb, which recruit MBP kinase activities with identical $M_{\mathrm{r}} \mathrm{s}$ (not shown; Shirvaikar, A., R. Singh, K. Schaeffer, M. Konieczkowski, and J.R. Sedor, manuscript in preparation), stimulate similar increases in CAT activity, further suggesting that these MBP kinases are required molecules for IL-1-activated cellular responses. IL$1 \alpha$ treatment of Rcd- and Rkb-expressing cells further enhanced CAT activity. However, the quantitative increase of CAT activity in IL-1-stimulated over unstimulated cells, transfected with IL-1Rcd expression constructs, was similar to that measured in cells transfected with control constructs. We be- 


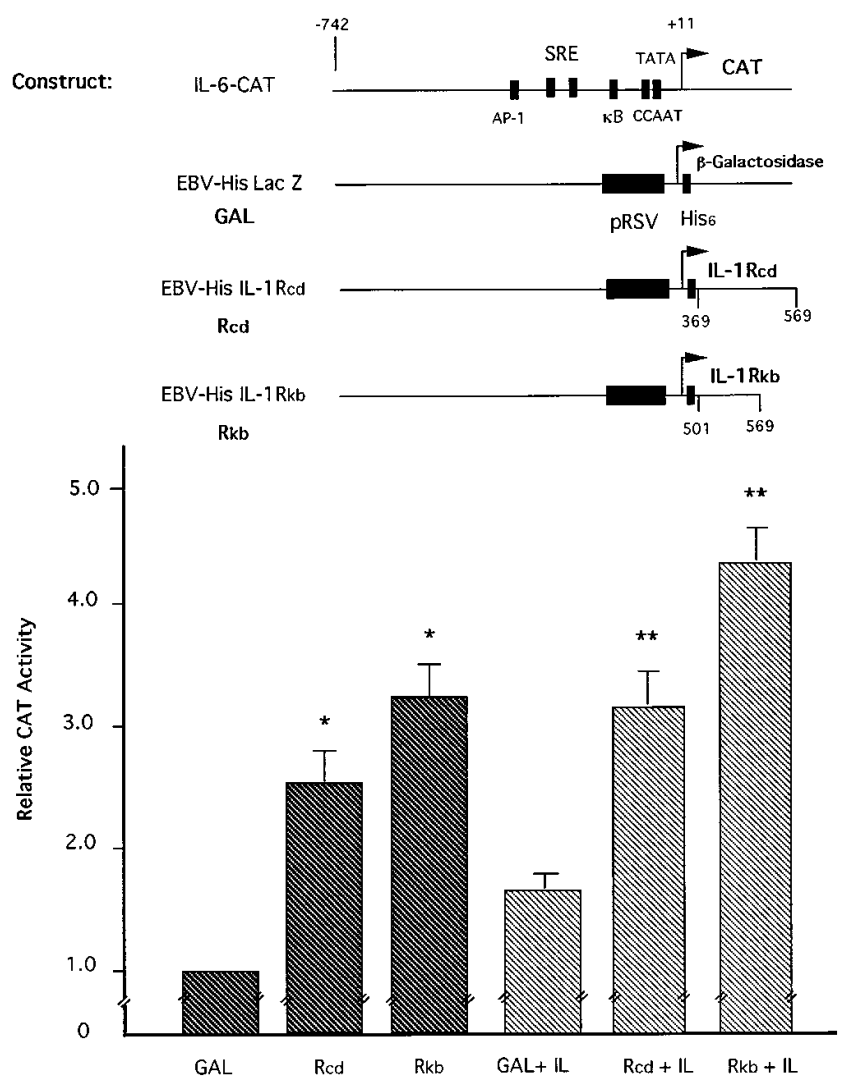

Figure 7. Expression of IL-cd in 293 cells stimulates IL-6 gene transcription. Human 293 cells stably expressing the EBNA-1 protein cells were cotransfected with a $5^{\prime}$-flanking region $(-742$ to +11$)$ IL-6-CAT reporter construct and either an IL-1Rcd eukaryotic expression vector $\mathrm{pEBV}$-HisBIL-1Rcd $(R c d)$, an expression vector containing IL-1Rcd sequences (amino acids 501-569) critical for NF- $\mathrm{B}$ activation and gene expression (references 4, 5, 7, 8; pEBV-HisBIL$1 \mathrm{Rkb}[R k b]$; Shirvaikar, A., R. Singh, K. Schaeffer, M. Konieczkowski, and J.R. Sedor, manuscript in preparation) or the control expression construct pEBV-HisLacZ (GAL) as shown in the top panel. Transfected cells were incubated for $20 \mathrm{~h}$ in the presence or absence of IL-1 $\alpha(20 \mathrm{ng} / \mathrm{ml})$ and CAT activity was determined as described in Methods. Results shown in the bottom panel are the mean \pm SEM of three independent experiments. $* P<0.01$, compared with unstimulated cells transfected with the GAL control vector; ** $P<0.01$, compared with IL-1-stimulated cells transfected with the GAL control vector; Kruskal-Wallis one way ANOVA with pairwise multiple comparisons by Student-Newman-Keuls method.

lieve therefore that the total CAT activity measurable in IL1Rcd-expressing cells represented additive effects of expressed IL-1cd protein and activation of endogenous IL-1R. Results from experiments using wild-type 293 cells were qualitatively similar (data not shown).

To assess whether protein kinases mediated the IL-1Rcddirected increases in CAT activity, 293-EBNA cells transfected with either Rcd or GAL were treated as described with either staurosporine, calphostin $\mathrm{C}$, or genistein in the indicated concentrations (Table I). CAT activity in cells transfected with the GAL construct was not significantly different in kinase inhibitor-treated and untreated cells. In contrast, the serine/ threonine kinase inhibitors calphostin $\mathrm{C}$ and staurosporine significantly reduced CAT activity in cells transfected with Rcd
Table I. Effect of Protein Kinase Inhibition on IL-6-directed CAT Activity

\begin{tabular}{clc}
\hline Expression construct & \multicolumn{1}{c}{ Treatment } & Relative CAT activity \\
\hline EBVHis-LacZ & None & 1.00 \\
$($ GAL $)$ & Staurosporine $(100 \mathrm{nM})$ & $1.17 \pm 0.21$ \\
& Calphostin C $(500 \mathrm{nM})$ & $0.87 \pm 0.14$ \\
& Genistein $(20 \mu \mathrm{M})$ & $1.08 \pm 0.14$ \\
EBVHis-ILRcde & None & 1.00 \\
$($ Rcd $)$ & Staurosporine $(100 \mathrm{nM})$ & $0.45 \pm 0.06^{*}$ \\
& Calphostin C $(500 \mathrm{nM})$ & $0.23 \pm 0.11^{*}$ \\
& Genistein $(20 \mu \mathrm{M})$ & $1.06 \pm 0.31$ \\
\hline
\end{tabular}

293-EBNA cells were transiently transfected with either a control mammalian expression plasmid [EBVHis-LacZ (GAL)], or a construct containing the cytosolic domain of the IL-1R [EBVHis-ILRcd (Rcd)] and the IL-6 5' flanking region-CAT chimeric reporter plasmid as described in Methods. Inhibitors at the indicated concentrations were added for the final $24 \mathrm{~h}$ of incubation. Results are expressed as the CAT activity normalized to the CAT activity present in the untreated sample within each construct group, mean \pm SEM ( $n=4$ independent experiments). CAT activity for the control plasmid (GAL) was $14,200 \pm 2,500$ compared with $69,000 \pm 8,500 \mathrm{cpm}$ for the ILRcd construct. $* P<0.05$, compared with the untreated sample for the indicated expression construct by one way ANOVA with pairwise multiple comparisons by Dunn's method.

(Table I). The tyrosine kinase inhibitors, genistein (Table I) or herbimycin (not shown), failed to reduce CAT activity in these cells. These results suggest that intact serine/threonine kinase activity is required for activation of downstream signaling events to result in a functional cell response, gene transcription. In contrast, MBP kinase-IL-1R association does not require the kinase activities blocked by these same inhibitors (Fig. 2).

\section{Discussion}

Little is understood at the molecular level about IL-1-receptor activation and postreceptor signaling events. The IL-1Rcd is essential for cellular responses to IL-1 (9), and IL-1 stimulates within minutes a number of biochemical processes, including sphingomyelin turnover, arachidonate release, GTP hydrolysis and tyrosine- and serine-threonine phosphorylation and dephosphorylation (1). Yet, despite the biological importance of IL-1 in initiating and propagating inflammatory tissue injury, only the putative kinase IRAK has been directly coupled with the IL-1R (11).

To further understand IL-1R function, we have used IL-1R immunocomplexes and recombinant GST fusion proteins to assay and characterize kinases that associate with the cd sequences of IL-1R. This approach provided direct biochemical evidence for interacting proteins from cell lysates. Consistent with the work of Cao et al. (11), we have found that three MBP kinases of 63,83 , and $100 \mathrm{kD}$ strongly interact with the IL-1Rcd. The $100-\mathrm{kD}$ protein is similar in size to IRAK, which was originally identified as a $100-\mathrm{kD}$ phosphoprotein that coprecipitated with the IL-1R from IL-1-stimulated 293 cells (8) and subsequently was cloned (11). Sequential immunoprecipitation and immunoblotting has demonstrated that IRAK physically associates with the IL-1R in an IL-1-dependent manner 
(8), and the aggregation of IL-1R and IRAK appears necessary for IL-1-mediated NF-кB activation (8). Kinase function has not been directly demonstrated for IRAK, although an IL-1dependent shift in IRAK mobility consistent with autophosphorylation was demonstrated $(8,11)$. An apparent murine homologue of IRAK, mouse Pelle-like protein kinase (mPLK), has kinase activity in vitro but has not been demonstrated to physically associate with IL-1R (19). The data presented in this paper identified a 100-kD MBP kinase that coprecipitates with both IL-1R immunocomplexes and GST-IL-1Rcd, but not a mutant fusion protein lacking $\mathrm{COOH}$-terminal sequences for IL-1-mediated signal transduction, and suggests that IRAK does function as a kinase.

The functional significance of these IL-1R-associated MBP kinases in mediating IL-1-stimulated cellular functions is suggested by two observations. First, a GST-IL-1R fusion protein (IL-1Rcd), which lacks critical amino acids essential for IL-2 (4) and IL-8 (5) transcription and NF-кB activation (7), poorly phosphorylates MBP in solution kinase assays (Fig. 4) and fails to coprecipitate with the 63-, 83-, and 100-kD MBP kinases in solid phase (in gel) assays (Fig. 5). Second, merely expressing either the IL-1Rcd sequences used in the wild-type GST-IL$1 \mathrm{R}$ fusion protein or the $\mathrm{COOH}$-terminal sequences necessary for NF-кB activation was sufficient to trigger transcription of the IL-1-inducible gene IL-6, even in the absence of IL-1 stimulation of the target cells (Fig. 7). This IL-1Rcd-mediated increase in IL-6 promoter-directed CAT activity was inhibited by the protein kinase inhibitors staurosporine and calphostin $\mathrm{C}$ (Table I), suggesting the functional effects of ectopic IL-1Rcd expression requires serine/threonine kinase activity.

Both our in vitro and in vivo data strongly suggest that IL$1 \mathrm{Rcd}$ sequences contained within the recombinant proteins, in the absence of the IL-1R extracellular and transmembrane domains, can spontaneously recruit and activate the signaling molecules necessary for IL-1-mediated cellular activation. Several mechanisms could explain these observations. One possibility is that wild-type secondary structure and protein folding may not be generated by either the bacterial or mammalian expression constructs used in these studies. The wildtype IL-1Rcd, in contrast with the recombinant Rcd molecules, may associate with a regulatory molecule(s) that represses MBP kinase association/activity. Our results support this premise, since assayed in solution (Fig. $1 A$ ), MBP kinase activity associated with IL-1R immunocomplexes was ligand dependent. In contrast, when assayed in gel (Fig. 5 B), MBP kinase activity coprecipitating with IL-1R was specific but ligand independent. The denaturing conditions used to separate IL-1Rassociated molecules in the solid phase kinase assay may have dissociated regulatory molecules.

A second explanation for IL-1Rcd-directed spontaneous signaling is that IL-1R aggregation may be necessary to activate downstream signals $(1,20)$. Most investigators have assumed IL-1R to be a single chain receptor, since transfection of Chinese hamster ovary cells with the IL-1R cDNA was sufficient to confer significant functional responses to IL-1 (21). However, IL-1-stimulated prostaglandin synthesis was suppressed in a second Chinese hamster ovary cell line, which overexpressed an IL-1R mutant lacking the entire cd. The presumed clustering of the low abundance, endogenous Chinese hamster ovary (wild type) with the excess, recombinant IL-1R (mutant) extracellular domains blocked signal transduction (21). Guo et al. recently provided more direct evidence for
IL-1-dependent IL-1R aggregation using fluorescence resonance energy transfer (20). The recombinant proteins used in our experiments may have formed IL-1 cd oligomers that mimicked IL-1R clustering necessary for recruitment/activation of downstream responses.

Although our data have demonstrated that recombinant IL-1Rcd proteins can spontaneously recruit and activate signaling molecules to stimulate functional responses, the wildtype IL-1R do not stimulate cellular biochemical and functional responses in the absence of IL-1. Cellular mechanisms must prevent spontaneous IL-1R activation and signal transduction. To some extent, spontaneous signaling is inhibited by the membrane-proximal region of the cd (Shirvaikar, A., R. Singh, K. Schaeffer, M. Konieczkowski, and J.R. Sedor, manuscript in preparation). In addition, our results suggest that the conformation of the wild-type extracellular IL-1R domains, in the absence of IL-1, may repress spontaneous signaling in whole cells by preventing recruitment/activation of the signaling molecules associated with the intracellular domains. Modeling studies have suggested that a region of the IL-1R that is important for biological function of IL-1 $\beta$ induces movement of the third immunoglobulin-like extracellular domain (22). Such a structural change caused by IL-1 binding could coordinately change the conformation of the IL-1Rcd to permit activation of signaling molecules. Interestingly, ultraviolet light, in the absence of IL-1, induced IL-1R clustering and JNK activation (23). These investigators suggested that energy absorption by membrane lipids and proteins may have lead to changes in IL-1R conformation similar to those initiated by IL-1.

Whether or not IL-1R multimerization or IL-1-mediated changes in IL-1R conformation are critical to signal transduction, data presented here and in an earlier study (6) indicate that the IL-1Rcd does not possess enzymatic activities. Either directly or indirectly through docking proteins, the IL-1Rcd must bind to downstream signaling molecules when activated. Both direct immunoprecipitation of IL-1R (24) and cross-linking of IL-1 to cells expressing IL-1R (references in 10) have suggested that the IL-1R is a multisubunit complex. An IL-1R accessory protein has been cloned and shown to increase binding affinity of the IL-1R for IL-1 (10), similar to the nonligand-binding subunits of the hematopoietic cytokines (25). The serine/threonine kinase IRAK is the only signaling molecule that has been shown to physically associate with the IL-1R after IL-1 treatment. IRAK subsequently recruits a new member of the TRAF protein superfamily of signal transducers, TRAF6, to activate NF-кB (26). Our data extend these observations by demonstrating that sequences within the IL-1Rcd associate physically with three MBP kinases and can direct IL-6 transcription, an effect blocked by serine/threonine kinase inhibitors.

The IL-1R is the prototype member of a growing family of transmembrane molecules with diverse or unknown functions that share significant sequence similarities within their cytoplasmic domains and can transmit IL-1-activated signals. The extracellular domains lack sequence homologies, suggesting that each binds distinct ligands to activate unique functions. These proteins include the Drosophila Toll transmembrane protein involved in establishing dorsal-ventral cell fate, the primary response gene Fit-1/T1/ST2, the human IL-1R-related protein, and the tobacco mosaic virus resistance gene $\mathrm{N}(4,27-$ 29). Molecular characterization of signaling pathways activated by the IL-1-IL-1R interaction may provide insights into 
the activation signals generated by the ligands of each of these proteins.

In summary, we propose that IL-1 binding to the extracellular domain of IL-1R induces a conformational change in the IL-1Rcd that results in (a) IL-1R self association, and/or (b) interaction with other cellular proteins, such as the IL-1R accessory protein. These protein-protein interactions result in the recruitment of activated signal molecules or unmasking of signaling activity in molecules constitutively associated with the receptor. Our data suggest that three of these molecules are 63-, 83-, and 100-kD MBP kinases. Early in inflammation, IL-1 is produced by infiltrating, activated macrophages as well as in lesser amounts by injured resident cells. A cascade of inflammatory responses ensues that, if unchecked, can lead to fibrosis and often organ failure. By further defining the proximate signaling events activated by IL-1 at the molecular level, novel targets for the therapy of inflammatory diseases may be identified.

\section{Acknowledgments}

The authors acknowledge the generous gift of recombinant human IL-1 $\alpha$ from Dr. Richard Chizzonite, Hoffman-LaRoche, and of the IL-6 5' flanking region-CAT gene chimeric plasmid from Dr. J. Vilchek, New York University Medical Center, New York, and thank Dr. Jeffrey Schelling for careful reading of the manuscript.

This work was supported by grants DK-38558 and DK-07470 from the National Institute of Diabetes and Digestive and Kidney Diseases and by a Grant-in-Aid from the American Heart Association.

\section{References}

1. Dinarello, C.A. 1996. Biologic basis for interleukin-1 in disease. Blood. 87:2095-2147.

2. Dinarello, C.A. 1991. Interleukin-1 and interleukin-1 antagonism. Blood. 77:1627-1652.

3. Dinarello, C.A. 1991. The proinflammatory cytokines interleukin-1 and tumor necrosis factor and treatment of the septic shock syndrome. J. Infect. Dis. 163:1177-1184.

4. Heguy, A., C.T. Baldari, G. Macchia, J.L. Telford, and M. Melli. 1992. Amino acids conserved in interleukin-1 receptors (IL-1Rs) and the Drosophila toll protein are essential for IL-1R signal transduction. J. Biol. Chem. 267:26052609.

5. Kuno, K., S. Okamoto, K. Hirose, S. Murakami, and K. Matsushima. 1993. Structure and function of the intracellular portion of the mouse interleukin 1 receptor (type I). Determining the essential region for transducing signals to activate the interleukin 8 gene. J. Biol. Chem. 268:13510-13518.

6. Gallis, B., K.S. Prickett, J. Jackson, J. Slack, K. Schooley, J.E. Sims, and S.K. Dower. 1989. IL-1 induces rapid phosphorylation of the IL-1 receptor. $J$. Immunol. 143:3235-3240.

7. Leung, K., J.C. Betts, L. Xu, and G.J. Nabel. 1994. The cytoplasmic domain of the interleukin-1 receptor is required for nuclear factor- $\mathrm{\kappa B}$ signal transduction. J. Biol. Chem. 269:1579-1582.

8. Croston, G.E., Z. Cao, and D.V. Goeddel. 1995. NF-kB activation by interleukin-1 requires an IL-1 receptor-associated protein kinase activity. J. Biol. Chem. 270:16514-16517.

9. Sims, J.E., M.A. Gayle, J.L. Slack, M.R. Alderson, T.A. Bird, J.G. Giri, F. Colotta, F. Re, A. Mantovani, K. Shanebeck, et al. 1993. Interleukin 1 signal- ing occurs exclusively via the type I receptor. Proc. Natl. Acad. Sci. USA. 90: 6155-6159.

10. Greenfeder, S.A., P. Nunes, L. Kwee, M. Labow, R.A. Chizzonite, and G. Ju. 1995. Molecular cloning and characterization of a second subunit of the interleukin 1 receptor complex. J. Biol. Chem. 270:13757-13765.

11. Cao, Z., W.J. Henzel, and X. Gao. 1996. IRAK: a kinase associated with the interleukin-1 receptor. Science (Wash. DC). 271:1128-1131.

12. Gronich, J., M. Konieczkowski, M.H. Gelb, R.A. Nemenoff, and J.R. Sedor. 1994. Interleukin $1 \alpha$ causes rapid activation of cytosolic phospholipase $\mathrm{A}_{2}$ by phosphorylation in rat mesangial cells. J. Clin. Invest. 93:1224-1233.

13. Frangioni, J.V., and B.G. Neel. 1993. Solubilization and purification of enzymatically active glutathione $S$-transferase (pGEX) fusion proteins. Anal. Biochem. 210:179-187.

14. Schendel, P., R.E. Kingston, and J. Sheen. 1994. Current Protocols in Molecular Biology. Greene Publishing Associates/Wiley \& Sons, Inc., New York

15. Dérijard, B., M. Hibi, I. Wu, T. Barrett, B. Su, T. Deng, M. Karin, and R.J. Davis. 1994. JNK1: a protein kinase stimulated by UV light and Ha-ras that binds and phosphorylates the c-jun activation domain. Cell. 76:1025-1037.

16. Whitmarsh, A.J., P. Shore, A.D. Sharrocks, and R.J. Davis. 1995. Integration of MAP kinase signal transduction pathways at the serum response element. Science (Wash. DC). 269:403-407.

17. Zhang, Y., J.-X. Lin, and J. Vilcek. 1990. Interleukin-6 induction by tumor necrosis factor and interleukin-1 in human fibroblasts involves activation of nuclear factor binding to a кB-like sequence. Mol. Cell. Biol. 10:3818-3823.

18. Ray, A., P. Sassone-Corsi, and P.B. Sehgal. 1989. A multiple cytokine and second messenger-responsive element in the enhancer of the human IL-6 gene: similarities with c-fos gene regulation. Mol. Cell. Biol. 9:5537-5547.

19. Trofimova, M., A.B. Sprenkle, M. Green, T.W. Sturgill, M.G. Goebl, and M.A. Harrington. 1996. Developmental and tissue-specific expression of mouse pelle-like protein kinase. J. Biol. Chem. 30:17609-17612.

20. Guo, C., S.K. Dower, D. Holowka, and B. Baird. 1995. Fluorescence resonance energy transfer reveals interleukin (IL)-1-dependent aggregation of IL-1 type I receptors that correlates with receptor activation. J. Biol. Chem. 270:27562-27568

21. Curtis, B.M., B. Gallis, R.W. Overell, C.J. McMahan, P. DeRoos, R. Ire2. J. Eisenman, S.K. Dower, and J.E. Sims. 1989. T-cell interleukin 1 receptor cDNA expressed in Chinese hamster ovary cells regulates functional responses to interleukin 1. Proc. Natl. Acad. Sci. USA. 86:3045-3049.

22. Vigers, G.P.A., L.J. Anderson, P. Caffes, and B.J. Brandhuber. 1997. Crystal structure of the type-I interleukin-1 receptor complexed with interleukin-1beta. Nature (Lond.). 386:190-194.

23. Rossette, C., and M. Karin. 1996. Ultraviolet light and osmotic stress: activation of the JNK cascade through multiple growth factor and cytokine receptors. Science (Wash. DC). 274:1194-1197.

24. Lewis, C., G. Mazzei, and A. Shaw. 1990. Monoclonal antibodies reacting with interleukin-1 receptor define a multi-receptor complex. Eur. J. Iтmиnol. 20:207-213.

25. Kishimoto, T., T. Taga, and S. Akira. 1994. Cytokine signal transduction. Cell. 76:253-262.

26. Cao, Z., J. Xiong, M. Takeuchi, T. Kurama, and D.V. Goeddel. 1996 TRAF6 is a signal transducer for interleukin-1. Nature (Lond.). 383:443-446.

27. Bergers, G., A. Reikerstorfer, S. Braselmann, P. Graninger, and M. Busslinger. 1994. Alternative promoter usage of the Fos-responsive gene Fit-1 generates mRNA isoforms coding for either secreted or membrane-bound proteins related to the IL-1 receptor. EMBO (Eur. Mol. Biol. Organ.) J. 13:11761188

28. Reikerstorfer, A., H. Holz, H.G. Stunnenberg, and M. Busslinger. 1995 Low affinity binding of interleukin-1 beta and intracellular signaling via NF-kB identify fit-1 as a distant member of the interleukin-1 receptor family. J. Biol. Chem. 270:17645-17648.

29. Mitcham, J.L., P. Parnet, T.P. Bonnert, K.E. Garka, M.J. Gerhart, J.L. Slack, M.A. Gayle, S.K. Dower, and J.E. Sims. 1996. T1/ST2 signaling establishes it as a member of an expanding interleukin-1 receptor family. J. Biol. Chem. 271:5777-5783.

30. Sims, J.E., R.B. Acres, C.E. Grubin, C.J. McMahan, J.M. Wignall, C.J. March, and S.K. Dower. 1989. Cloning the interleukin 1 receptor from human T cells. Proc. Natl. Acad. Sci. USA. 86:8946-8950. 